\title{
RAPTOR MORTALITY \\ ON NORTHEASTERN \\ BRITISH COLUMBIA TRAPLINE
}

CHRIS SIDDLE, 8927 116th Avenue, Fort St. John, British Columbia. V1J 2 Y2

In The Great Gray Owl, Robert Nero speculated that traps set for furbearing animals must kill many owls and that "in view of the number of trappers working with the range of the Great Gray Owl, trapping may be a mortality factor of considerable significance"."

Some recent experiences that I have had in the Fort. St. John area of northeastern British Columbia cause me to agree with Nero and, in fact, wonder if perhaps trapping might be not only a significant mortality factor, but also a particularly pernicious and often overlooked one.

Over the past four winters I have been allowed to view some (but not all) of the birds, mostly raptors, accidentally killed in the 350 traps of a single trapper who maintains two short traplines, one about $50 \mathrm{~km}$ west of Fort St. John and the other about 100 $\mathrm{km}$ north of the city.

From late 1980 to March 1984, his two lines have accounted for the deaths of two Boreal Owls, four Great Horned Owls, one Great Gray Owl, one Barred Owl, three Northern Goshawks and several Gray Jays.

The first Boreal Owl, killed during the winter of 1980-81 north of Farrell Creek, had the back of its skull crushed. The second Boreal Owl was caught across its left side in a lynx trap on 27 February 1984, at the confluence of Black Creek and the Beatton River. The Great Gray Owl was found frozen, with wings outstretch-

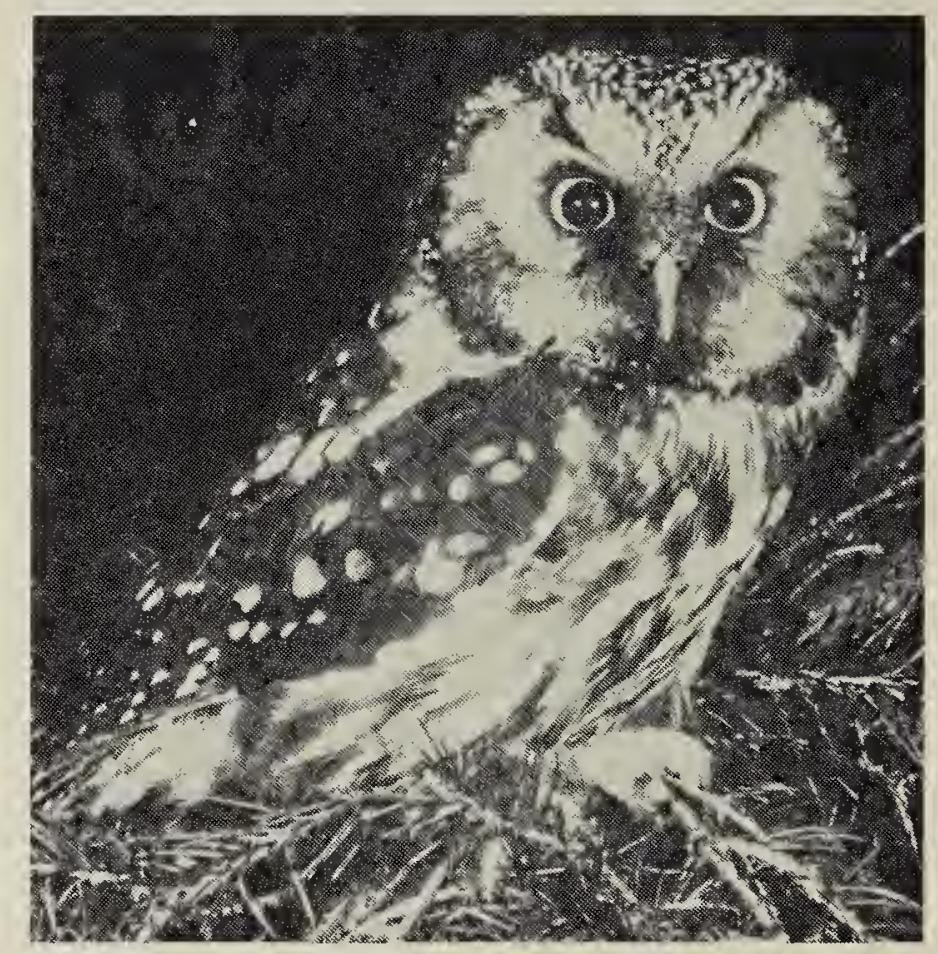

Boreal OWl

Chris Rees

ed, both feet caught in a leghold trap, in early January 1982. The Barred Owl had its chest crushed in a trap sometime in February 1981. Both of these birds were killed north of Farrell Creek.

The trapper has mentioned that there have been other raptors killed that I have not been shown or told of.

Thus for two traplines in four winters a minimum of eleven owls and hawks of five species have been accidentally killed. In view of the fact that trapping remains a common practice in northern and central Canada, the effects of accidental trapline mortality on raptor populations remains virtually unstudied but deserving of attention.

' NERO, R.W. 1980. The Great Gray Owl:

Phantom of the Northern Forest.

Smithsonian Inst. Press, Washington, D.C. 